УДК 621.314.632:572:472.001.5

DOI: $10.22213 / 2413-1172-2021-1-96-101$

\title{
Mathematical Modeling and Controller for PV System by Using MPPT Algorithm
}

H.A. Issa, Post-graduate, Institute of Nuclear Energy and Industry of Sevastopol State University, Sevastopol, Russia H.J. Mohammed, Post-graduate, Institute of Energy of Peter the Great St. Petersburg Polytechnic University, St. Petersburg, Russia

L.M. Abdali, Post-graduate, Institute of Nuclear Energy and Industry of Sevastopol State University, Sevastopol, Russia

A.G. Al Bairmani, Post-graduate, Institute of Nuclear Energy and Industry of Sevastopol State University, Sevastopol, Russia

M. Ghachim, PhD in Physics and Mathematics, Institute of Information Technologies and Management in Technical Systems, Sevastopol State University, Sevastopol, Russia

In this research, the study theory of system includes the use of an important source of renewable energy sources (solar source) and linking this system with an electrical load. The world is witnessing a significant rise in fossil fuel prices since the ending of the 20th century and now, this rise in price increases with the decrease in inventory day after day. Therefore, it turned that the field of attention to researchers of power generation to expand in nonconventional energy sources (new and renewable energy sources).

New and renewable energy is inexhaustible in use because they rely on renewable natural resources. The mathematical model is an important part of the detailed study for PV systems. As well as study models for photovoltaic systems via the MATLAB/Simulink, this programming environment contains many models for renewable systems intended to perform simulation and analysis.

Solar cells system needs to apply the MPPT algorithm due to the instability of external circumstances such as solar radiation and temperature.

At a constant temperature of $25^{\circ} \mathrm{C}$, as the radiation level increases, the current and voltage of the module increase, this leads to an increase in output power. At a constant radiation level of $100 \mathrm{~W} / \mathrm{m} 2$, as the module temperature increases, the current increases and the voltage decreases, this causes the output power to decrease. The maximum power is reached at $17 \mathrm{~V}$ and $3.5 \mathrm{~A}$ by the MPPT method. The Perturb and Observe algorithm is used to achieve maximum power.

Keywords: PV module, MPPT algorithm, voltage source multilevel inverter, mathematical modeling.

\section{Introduction}

$\mathrm{S}$ olar panel generation becoming and more main as a renewable power foundation as it offers many advantages over other sources such as not being polluting, incurring no energy costs, requiring small preservation and emitting no sound. PV panel still has comparatively low change efficiency, so, controlling Maximum power point tracking (MPPT) for a solar panel is important in a photovoltaic system [1]. The amount of energy generated by a photovoltaic panel depends on the panel voltage used [2]. The PV Maximum Power Point (MPP) depends on the climatic rays and temperature. From the $P V V-I$ and $V-P$ characteristic curves, the unique duty point at which the maximum possible power is generated can be determined. In MPPT, the photovoltaic system operates at maximum efficiency. Therefore, several algorithms have been developed to determine MPPT $[3,4]$. Others have used a new three-point weighting method that avoids the problem of fluctuations in the perturbation and observation algorithm that is often used to track the maximum power point, solar energy that can be gained by with a photovoltaic panel is able to change sunshine to electricity, the price of PV unit is still expensive and greatest power point of power is easily changed by surroundings factors such as solar rays, temperature, load, etc. In addition, to get solar energy as much as potential form PV module, the process of maximum power point $\mathrm{PV}$ module must be controlled because the alteration efficiency of the PV module is very low [5]. PV array needs sturdiness control concerning parameter variation due to non-linear characteristics. Forwarded a study and implementation of real-time Estimate - Perturb-Perturb algorithm for max power point tracking control in the photovoltaic system [6]. The MP and O algorithm recover the $\mathrm{P}$ and $\mathrm{O}$ algorithm at the cost of speed reply to changes of irradiance. In a new system, named the Estimate - Perturb-Perturb algorithm was forwarded through the authors, which displayed a good performance. Perturbation - Observation and PID controllers are used in this work to 
improve the $P V$ panel performance and tracking the maximum power under the weather conditions such as radiation and temperature [7-9]. A comparison between simulation and experimental results according to the Perturbation - Observation algorithm as well as the PID controller algorithm was performed [10].

\section{Mathematical sample of $P V$ panel}

The solar cell is the constitutive element of $P V$ arrays, it is essentially a $p-n$ semiconductor connection shown in Figure 1. The $V-I$ special equation 1 gives equation of a solar array [11].

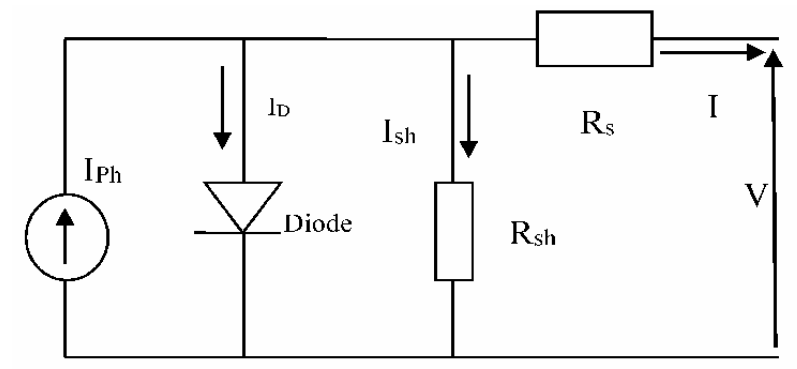

Fig. 1. PV mathematical model of the PV panel

$$
I=I_{s c}-I_{0}\left[\exp \left\{\frac{q\left(V+R_{s} I\right)}{n k T_{K}}\right\}-1\right]-\frac{V+R_{s} I}{R_{s h}},
$$

where $V, I$ - current and voltage for output PV panel; $R_{s}, R_{s h}$ - resistance of the panel in series and parallel; $q$ - electronic charge; $I_{s c}$ - light generated current; $I_{0}$ - reverse diffusion current; $n$ - factor for dimensionless; $k$ - Boltzmann constant; $T_{K}$ temperature in Kelvin.

The cell parameters are shown in the table 1 $[12,13]$.

\section{Table 1. Photovoltaic panel parameters [14]}

\begin{tabular}{|l|c|}
\hline Panel number & 1 \\
\hline Dimension $(\mathrm{cm})$ & $158 \times 8.08 \times 4$ \\
\hline Maximum power (w) & 200 \\
\hline Open circuit voltage (v) & 45.62 \\
\hline Maximum circuit voltage (v) & 37.26 \\
\hline Maximum circuit current (A) & 5.37 \\
\hline Wight (Kg) & 15.5 \\
\hline Short circuit current (A) & 5.66 \\
\hline
\end{tabular}

\section{Perturbation and Observation (P\&O)}

\section{Algorithm}

This algorithm is based on producing a slight perturbation by the system; the perturbation causes a change in the solar module power [15]. If the power is increased, the perturbation must be kept on in that direction, otherwise, reverse the perturbation direction $[16,17]$. The power of the panel starts decreasing after reaching the peak value for a certain period that is why the perturbation reverses its direction. At steady-state case, the system oscillates about the peak power point. When the power reaches the peak value, the power variation will be small [18-20]. The flowchart of the P\&O algorithm of the maximum power tracking isshown in figure 2, where $V(n), I(n)$ and $P(n)$ - are the current-voltage, current and power of the PV panel respectively [21].

\section{Simulink of the Photovoltaic system}

Photovoltaic array connected to a $25 \mathrm{kV}$ network through a DC-to-DC boost converter and a 3-phase 3-level voltage converter. Maximum Power Point Tracking (MPPT) is realized in the boost converter using a Simulink model using the technic of the neural network technique [22].

The contains of the average modelis

$P V$ array delivering a maximum power of $(100 \mathrm{~kW})$ at $\left(1000 \mathrm{~W} / \mathrm{m}^{2}\right)$ sun irradianc and Average model of voltage source converter. The voltage source converter 500-260 V (DC-AC) and keeps the unity power factor [23].

Figure 3 shows a Simulink diagram of a proposed system that uses a solar panel and a buck $D C$-DC converter controlled by an MPPT controller. The system is used to produce three output voltages and currents.

\section{Results and Discussion}

The proposed $P V$ module was Simulink by using dialogue box from block Libraries in MATLAB. The results are as follows:

- Figure 4 shows the $I-V, P-V$ and $P-I$ characteristics for different values of solar irradiation $\left(400,700\right.$ and $\left.1000 \mathrm{~W} / \mathrm{m}^{2}\right)$ at constant temperature $\left(25^{\circ} \mathrm{C}\right)$, when the irradiation increases, the power and current increase as shown in fig. $4, a, b$ respectively.

- Figure 5 shows the $I-V, P-V$ and $P-I$ characteristics for different values of temperature $(25$, 35 and $45^{\circ} \mathrm{C}$ ) at constant irradiation $\left(1000 \mathrm{~W} / \mathrm{m}^{2}\right)$ Here, when the operating temperature increases, the power and output voltage decreases as shown in Figure $5, a, b$. The value of power is $60 \mathrm{~W}$ at temperature $25^{\circ} \mathrm{C}$, and decreases when the temperature increases.

- From the $P V$ characteristics, we can observe that there is a point at which the power output is maximum, which gives the maximum efficiency. In the Standard Test Conditions, itwas found that the proposed $P V$ Emulator produces the maximum power at $60 \mathrm{~W}$ with voltage $17 \mathrm{~V}$ and current $3.8 \mathrm{~A}$ with increasing irradiation at a constant temperature. For comparison, according to the datasheet, at 
Standard Test Conditions, the MSX-60 solar module produces the maximum power $60 \mathrm{~W}$ with the voltage at the maximum power of $17.1 \mathrm{~V}$ and current of $3.5 \mathrm{~A}$.

- Figure $6, a, b$ shows the continuous level of the $V_{p n}$ and $I_{p n}$ values respectively, that is fed to MPPT controller to produce the switching signal of the required duty cycle as shown in Figure. 6, c to control the DC-DC buck converter to achieve maximum efficiency. The output of MPPT is a signal for two operating conditions, the duty Interval $\left(T_{o n}\right)$ and the freewheeling mode $\left(T_{o f f}\right)$. However, these MPPT pulses more convenient for regulating the output voltages of the Buck DC-DC converter.

For this proposed design, the module formed by connecting $36 \mathrm{PV}$ cells in series. The output voltage can be calculated by multiplying the cell voltage by the number of the cells, while the total current is equal to the cell current (Fig. 7).

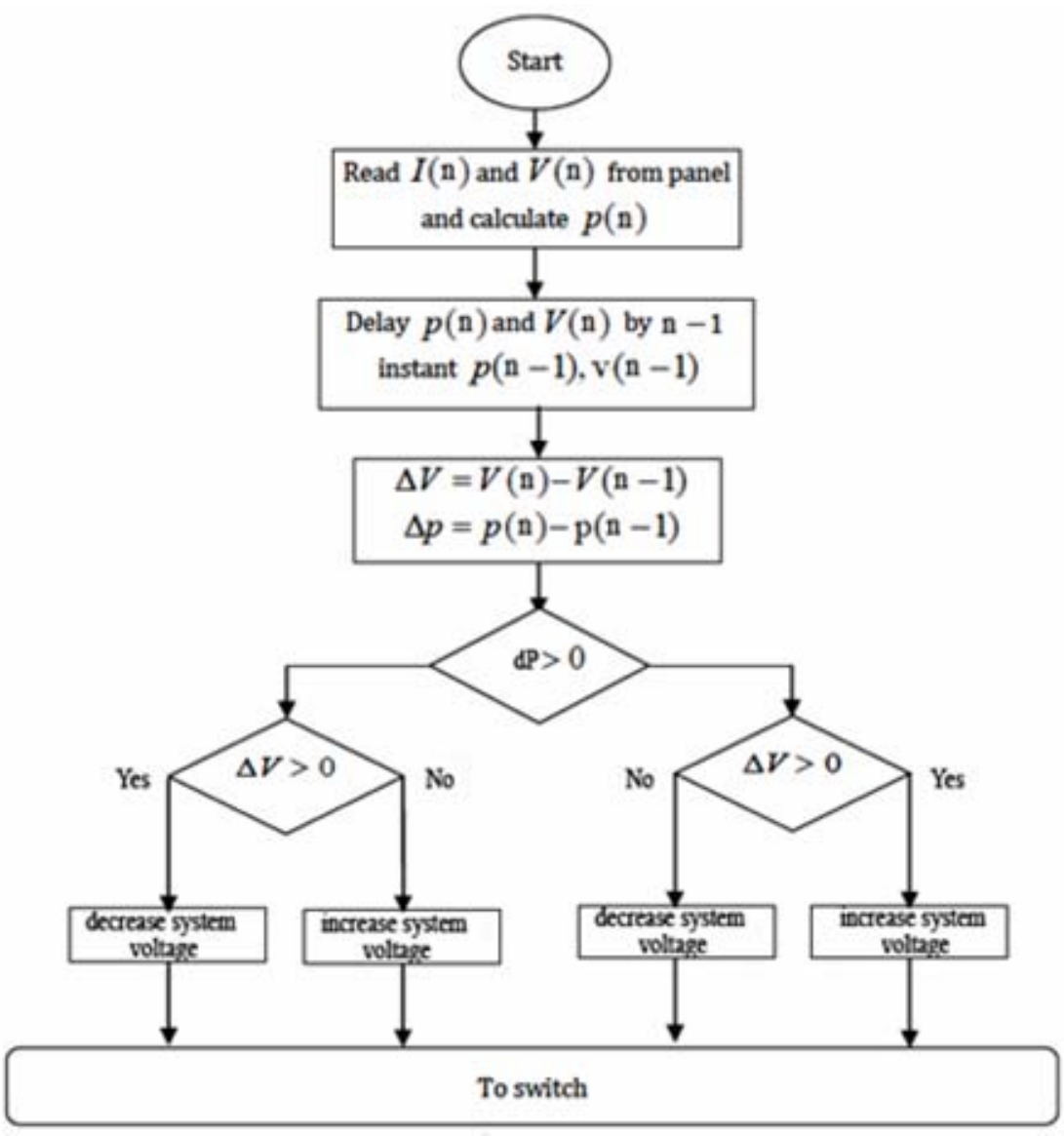

Fig. 2. The block diagram of the algorithm "Perturbation and observation" method

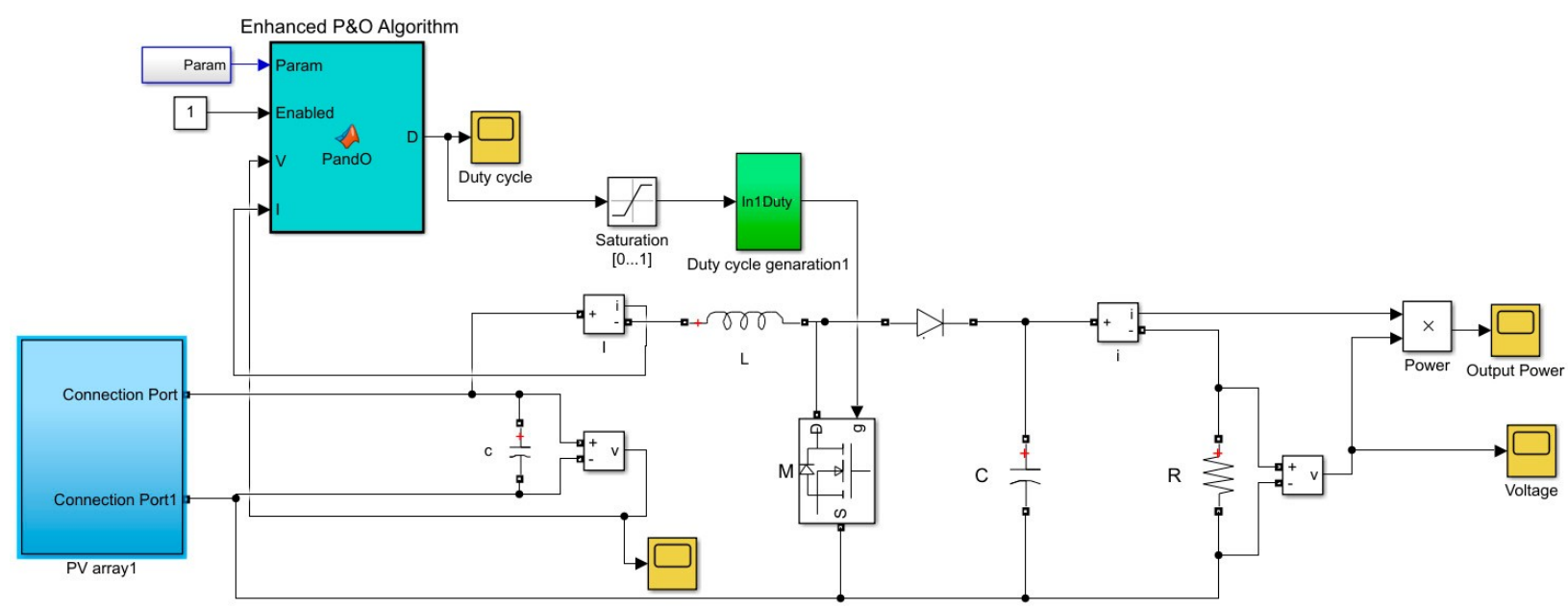

Fig. 3. Model of solar $P V$ emulator utilizing buck converter 


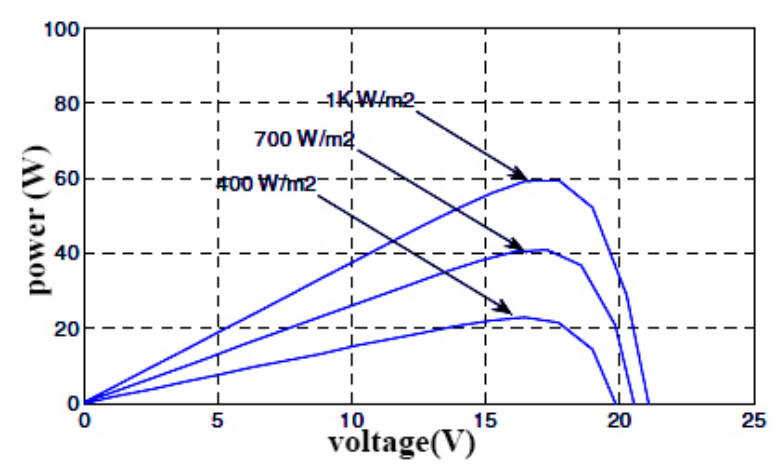

a

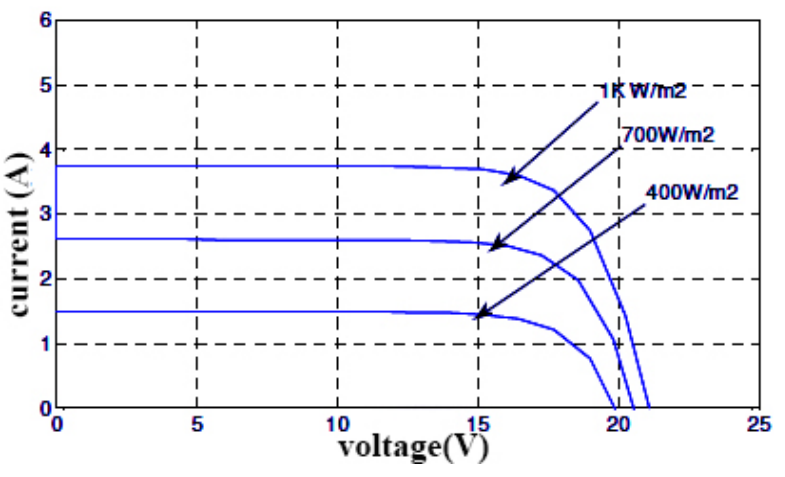

$b$

Fig.4. $P-V(a), I-V(b)$ characteristics at $T=25^{\circ} \mathrm{C}$

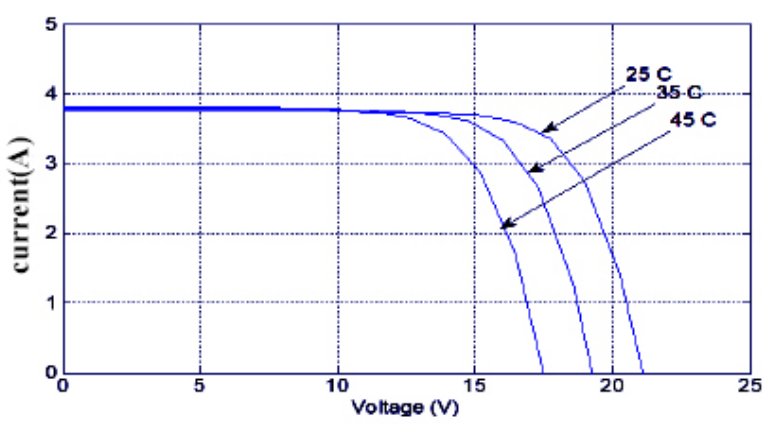

a

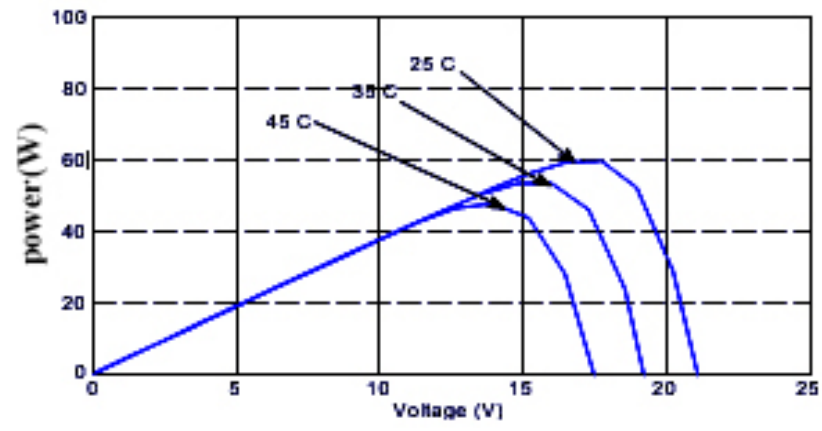

$b$

Fig. $5 . I-V(a), P-V(b)$ characteristics at $S=1000 \mathrm{~W} / \mathrm{m}^{2}$

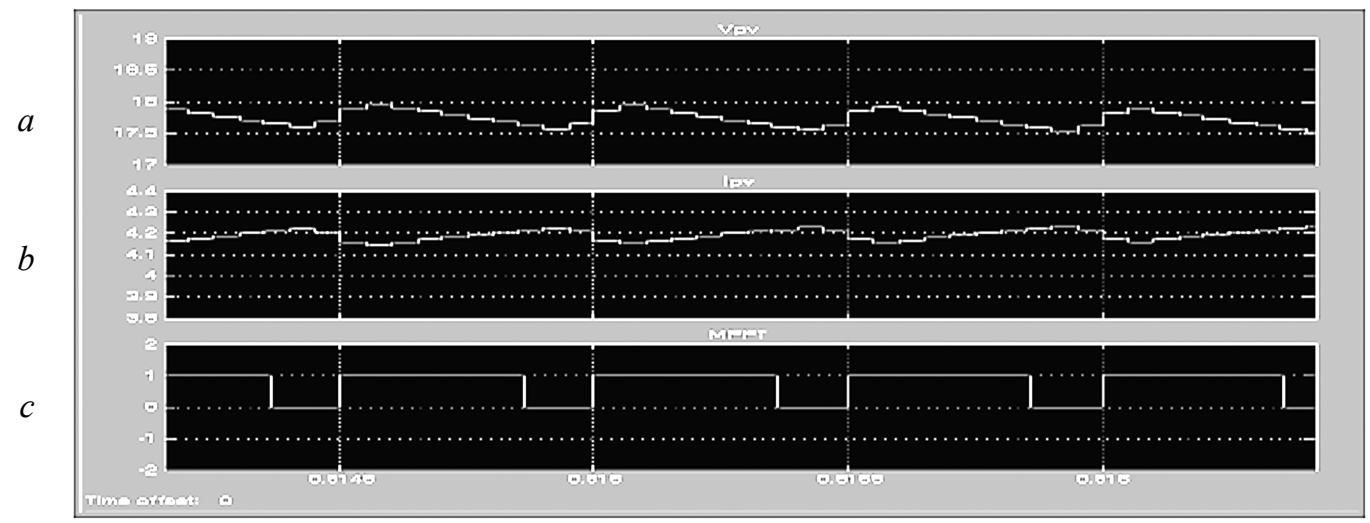

Fig. 6. $V_{p n}, I_{p n}$ and MPPT switching waveforms

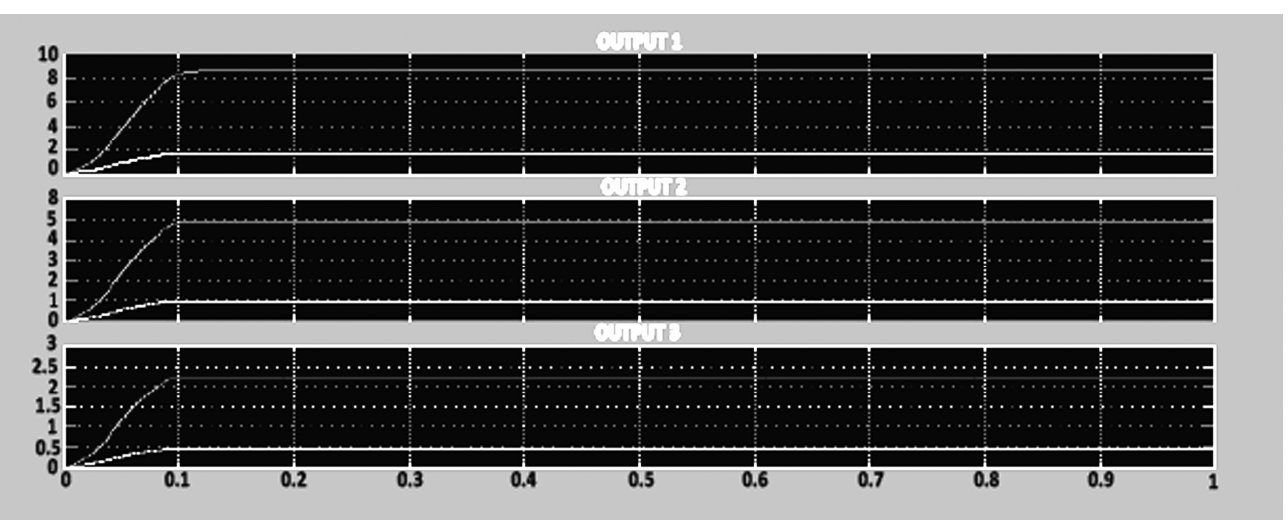

Fig. 7. Simulink results for output currents and voltages 
Figure 7 shows the simulated waveforms of three output voltages and currents, here approximate values of the first output voltage of circuit is $9 \mathrm{~V}$ and current is $2 \mathrm{~A}$, the second output voltage is about $5 \mathrm{~V}$ and current is about $1 \mathrm{~A}$, and the third output voltage is about $2.2 \mathrm{~V}$ and current is about $0.5 \mathrm{~A}$.

\section{Conclusions}

A Matlab/Simulink model for the PV solar panel with Multiple Outputs DC-DC Converter controlling by MPPT Technique was developed and presented in this paper. The PV system module is design depending on the circuit equations of solar cell model. The electrical characteristics $(P-V, I-V$ and $P$ - $I$ curves) are achieved for the solar module that explains its dependence on the solar radiation and atmospheric temperature. When temperature remains constant at $25^{\circ} \mathrm{C}$, and the radiation increases, the current and voltage of the cell model increase, this leads to an increase in the output power. In addition, when the radiation level keeps constant at $100 \mathrm{~W} / \mathrm{m}^{2}$ and the cell temperature increases, the current increases, but the voltage decreases, this leads to reduce in output power.

The maximum power achieved at voltage $17 \mathrm{~V}$ and current 3.5 A with MPPT technique. The Perturb and Observe algorithm is used for achieve Maximum Power Point. The regulator outputs of buck converter controlling by the signal feds from MPPT controller are achieved successively.

\section{References}

1. Abd Ali L.M.A., Al-Rufaee F.M., Yakimovich B.A., Kuvshinov V.V. [Performance Analysis of Hybrid PhotoWind Turbines]. Energeticheskiye ustanovki i tekhnologii, 2019, vol. 5, no. 2, pp. 61-68 (in Russ.).

2. Abo-Elyousr F.K., Abdelshafy A.M., Abdelaziz A.Y. MPPT-Based Particle Swarm and Cuckoo Search Algorithms for PV Systems. In Modern Maximum Power Point Tracking Techniques for Photovoltaic Energy System, Springer: Cham, Switzerland, 2020, pp. 379-400.

3. Abd Ali L.M., Al-Rufai F.M., Yakimovich B.A., Kuvshinov V.V., Issah.A., Mohammed H.D. [The generation power plant by using the combined of solar and wind power]. Mezhdunarodnaya nauchno-prakticheskaya konferentsiya "Ekologicheskaya, promyshlennaya i energeticheskaya bezopasnost' - 2020” [International Scientific and Practical Conference "Environmental, Industrial and Energy Safety - 2020"]. Sevastopol', SevGU, 2020, pp. 21-28 (in Russ.).

4. Zhang Q., Ning Xu., and Z. Ye. MMPT control method for photovoltaic power supply based on improved variable-step hill-climbing method. Electric Engineering, 2018, vol. 2, pp. 55-57.

5. Kuvshinov V.V., Abd Ali L.M., Kakushina E.G. Studies of the PV Array Characteristics with Changing
Array Surface Irradiance. Appl. Sol. Energy, 2019, vol. 55, no. 4, pp. 223-228.

6. Cheboxarov V.V., Yakimovich B.A., Lyamina, N.V. Some Results of a Study of Wave Energy Converters at Sevastopol State University. Appl. Sol. Energy, 2019, vol. 55 , no. 4 , pp. 256-259.

7. Vologdin S.V., Yakimovich B.A., Kuvshinov V.V. Analysis of Various Energy Supply Scenarios of Crimea with Allowance for Operating Modes of Solar Power Planta. Appl. Sol. Energy, 2019, vol. 55, no. 4, pp. 229-234.

8. Cheboxarov V.V., Yakimovich B.A., Abd Ali L.M. An Offshore Wind-Power-Based Water Desalination Complex as a Response to an Emergency in Water Supply to Northern Crimea. Appl. Sol. Energy, 2019, vol. 55, no. 4, pp. 260-264.

9. Guryev V.V., Yakimovich B.A., Abd Ali L.M. Improvement of Methods for Predicting the Generation Capacity of Solar Power Plants: the Case of the Power Systems in the Republic of Crimea and City of Sevastopol. Appl. Sol. Energy, 2019, vol. 55, no. 4, pp. 242-246.

10. Ahmed M.H., Anssari M.O.H., Abd Ali L.M. Electricity generation by using a hybrid system (photovoltaic and fuel cell). J. Eng. Appl. Sci., 2019, no. 14, pp. 4414-4418. doi.org/10.3923/jeasci.2019.4414.4418.

11. Abd Ali L.M., Mohmmed H.A. and Abdulhusein H.W. A Novel Design of 7-Level Diode Clamped Inverter. Journal of Engineering and Applied Sciences, 2019, no. 14, pp. 3666-3673. doi.org/10.36478/ jeasci.2019.3666.3673.

12. Kuvshinov V.V., Kolomiychenko V.P., Kakushkina E.G. Storage System for Solar Plants. Appl. Sol. Energy, 2019, vol. 55, no. 3, pp. 153-158.

13. Kuznetsov N.P., Abd Ali M.L., Kuvshinov V.V., Issa A.H., Mohammed J.H., \& Al-bairmani G.A. Investigation of the losses of photovoltaic solar systems during operation under partial shading. Journal of Applied Engineering Science, 2020, vol. 18, no. 3, pp. 313-320. doi :10.5937/jaes18-24460.

14. Abd Ali L.M., Al-Rufaee F.M., Kuvshinov V. V. Study of Hybrid Wind-Solar Systems for the Iraq Energy Complex. Appl. Sol. Energy, 2020, vol. 56, no. 4, pp. 284-290. doi.org/10.3103/S0003701X20040027.

15. Aouchiche N., Aitcheikh M.S., Becherif M., Ebrahim M.A. AI-based global MPPT for partial shaded grid connected PV plant via MFO approach. Sol. Energy, 2018, vol. 171, pp. 593-603.

16. Pathy S., Subramani C., Sridhar R., Thentral T., Padmanaban S. Nature-inspired MPPT algorithms for partially shaded PV systems. A comparative study Energies, 2019, vol. 12, p. 1451.

17. Abd Ali L.M., Ahmed Mohmmed H., Anssari M.O.H. Modeling and simulation of tidal energy. J. Eng. Appl. Sci., 2019, no. 14, pp. 3698-3706. doi.org/10.3923/jeasci.2019.3698.3706.

18. Abdali L.M., Kuvshinov V.V., Bekirov E.A., AlRufaee F.M. Development of the simulation and control system for an integrated solar energy generation and storage. Construction and industrial safety, 2020, no. 18, pp. 133-142. doi: 10.37279/2413-1873-2020-18-133-142. 
19. Faza M.R., Kamran M., ulHaq I., Abbas Z., Ayyaz M.N., Mudassar M. Modified Perturb and Observe MPPT algorithm for partial shading conditions. Int. J. Renew. Energy Res., 2019, vol. 9, pp. 721-731.

20. Belkaid A., Colak I., Kayisli K. Implementation of a modified P\&O-MPPT algorithm adapted for varyingsolar radiation conditions. Electr. Eng., 2017, vol. 99, pp. 839-846.

21. Abdali L.M., Al-Rufai F.M., Yakimovich B.A., KuvshinovV.V. [Optimization of Energy Storage in HybridWind and Photovoltaic Energy Systems]. Vestnik IzhGTU imeni M.T. Kalashnikova, 2020, vol. 23, no. 2, pp. 100-108 (in Russ.). DOI: 10.22213/2413-1172-2020-2-100-108.
22. Abdali L.M., Al-Rufai F.M., Mohammed H.D., Yakimovich B.A., Kuvshinov V.V. Modeling of a hybrid photo-wind power system with a mains connection. $V o-$ zobnovlyayemyye istochniki energii: Materialy Vserossiyskoy nauchnoy konferentsii s mezhdunarodnym uchastiyem $i$ XII nauchnoy molodezhnoy shkoly [Renewable Energy Sources: Proceedings of the All-Russian Scientific Conference with International Participation and XII Scientific Youth School], 2020, pp. 117-128 (in Russ.).

23. Jave, K., Ashfaq H., Singh R. A new simple MPPT algorithm to track MPP under partial shading for solar photovoltaic systems. Int. J. Green Energy, 2020, vol. 17 , pp. 48-61.

\section{Математическое моделирование и контроллер для фотоэлектрической системы с использованием алгоритма МРPТ}

$X$. А. Исса, аспирант, Севастопольский государственный университет, Севастополь, Россия $X$. Д. Мохаммед, аспирант, Санкт-Петербургский политехнический университет Петра Великого, Санкт-Петербург, Россия

Л. М. Абдали, аспирант, Севастопольский государственный университет, Севастополь, Россия А. Г. Аль Баирмани, аспирант, Севастопольский государственный университет, Севастополь, Россия M. Гхашим, кандидат физико-математических наук, Севастопольский государственный университет, Севастополь, Россия

Теория системного исследования включает использование важного источника возобновляемой энергии солнечной радиации - и связывает эту систему с электрической нагрузкой. В мире наблюдается значительный рост ичен на ископаемое топливо; с конца 20-го века и до настоящего времени эта тенденция продолжается, при этом запасы традиционного органического топлива постоянно сокращаются. В связи с этим внимание исследователей в области выработки электроэнергии сосредоточено на вопросе расширения использования нетрадиционных источников энергии (альтернативных и возобновляемых видов энергии).

Новая альтернативная энергетика является неисчерпаемой в использовании, потому что она полагается на возобновляемые природные ресурсы. В данном исследовании представлено подробное описание использования фотоэлектрических преобразователей и систем с различными типами солнечных элементов. Математическая модель является важной частью подробного исследования фотоэлектрических систем. Исследование модели фотоэлектрических систем выполнено в MATLAB/Simulink.

При математическом моделировании систем солнечных модулей использован алгоритм МРРТ из-за нестабильности внешних условий, таких как солнечное излучение и температура.

При постоянной температуре $25{ }^{\circ} \mathrm{C}$, при увеличении излучения ток и напряжение модуля увеличиваются, что приводит к увеличению выходной мощности. При постоянном уровне излучения $100 \mathrm{Bm} / \mathrm{m}^{2}$, при повышении температуры модуля ток увеличивается, а напряжение уменьшается, это приводит к уменьшению выходной мощности. Максимальная мощуность достигается при напряжении 17 B и токе 3,5 A по методу МРРТ. Для достижения максимальной мощьности используется алгоритм Perturband Observe.

Ключевые слова: фотоэлектрический модуль, алгоритм МРРТ, многоуровневый инвертор источника напряжения, математическое моделирование.

Получено 29.01.2021

\section{For Citation}

Issa H.A., Mohammed H.J., Abdali L.M., Al Bairmani A.G., Ghachim M. Mathematical Modeling and Controller for PV System by Using MPPT Algorithm. Vestnik IzhGTU imeni M.T. Kalashnikova, 2021, vol. 24, no. 1, pp. 96-101. DOI: 10.22213/2413-11722021-1-96-101. 